\title{
Post-Operative Peritonitis: Diagnostic Problems, Morbidity and Mortality in Developing Countries
}

\author{
Alhassane Traoré1,2* Bakary Tientigui Dembélé1,2, Adégné Togo ${ }^{1,2}$, Lassana Kanté1,2, \\ Madiassa Konaté1,2, Ibrahima Diakité2, Simo Notue Fabienne Laurence ${ }^{2}$, \\ Boubacar Karembé ${ }^{2}$, Abdoulaye Diarra², Amadou Traoré2 \\ Mahamane Djibo Diango 1,3, Gangaly Diallo',2 \\ ${ }^{1}$ Faculty of Medicine and Odonto-Stomatology, Bamako, Mali \\ ${ }^{2}$ Department of General Surgery, CHU Gabriel Touré, Bamako, Mali \\ ${ }^{3}$ Department of Anesthesia and Intensive Care, CHU Gabriel Touré, Bamako, Mali \\ Email: *Alhassanetraore2008@yahoo.fr
}

Received 25 May 2014; revised 24 June 2014; accepted 22 July 2014

Copyright (C) 2014 by authors and Scientific Research Publishing Inc.

This work is licensed under the Creative Commons Attribution International License (CC BY).

http://creativecommons.org/licenses/by/4.0/

c) (i) Open Access

\section{Abstract}

Goal: To study the diagnostic difficulties and post-operative morbidity and mortality of peritonitis. Patients and Methods: Retrospective study about the records of adult patients operated on between 1999 and 2013 whose diagnosis of post-operative peritonitis was made. Results: We achieved 23,573 lanterns and recorded 148 cases of postoperative peritonitis or $0.62 \%$. The medium age was $37.1 \pm 17.7$ years and the sex ratio was 1.2 . The delay between the initial intervention and reoperation was less than 5 days. Factors occurrence of postoperative peritonitis were those related to the initial surgery: septic context $70.8 \%$, emergency surgery $81.1 \%$ under the seat mesocolic $25 \%$ and $20.3 \%$ initial surgical technique. The diagnosis was made preoperatively in $62.2 \%(n=92)$. Ultrasound has found an effusion in $29.7 \%(n=44)$. Cytobactériologic review identified germs in $85.1 \%(n=126)$ and sterile in $12.9 \%$ of patients $(n=22)$. The most frequent etiologies were: $22.9 \%$ anastigmatic leak $(n=34)$, the phoenix abscess in $17.6 \%(n=26)$, iatrogenic perforation $13.5 \%(n=20)$ and digestive fistula $25 \%(n=37)$. Other causes were the stoical necrosis $12.2 \%(n=18)$ and evisceration $8.8 \%(n=13)$. We performed a digestive stoma in $61 \%$ $(n=89)$, a closure of the abdomen bolsters in $8.8 \%(n=13)$, a suture in iatrogenic perforation in $13.5 \%(n=20)$ and washing with drainage in patients with phoenix abscess in $17.6 \%(n=26)$. Morbidity was $\mathbf{2 2 . 3 \%}$ and $\mathbf{5 3 . 4 \%}$ mortality. Conclusion: The diagnosis of post-operative peritonitis is difficult in a developing country. Morbidity and mortality is high. Improved diagnostic tools are needed.

*Corresponding author. 


\section{Keywords}

\section{Peritonitis, Postoperative Morbidity and Mortality, Surgery}

\section{Introduction}

Postoperative peritonitis poses a diagnostic and treatment challenge to practitioners. They are the most feared complication tank with a mortality ranging from $30 \%$ to $71 \%$ according to the literature [1]-[4]. This mortality is linked to visceral multi failures it causes. We initiate this study to determine the diagnostic difficulties and preand postoperative complications they entail in our country.

\section{Patients and Methods}

It was about a retrospective study of the records of patients operated on between 1999 and 2013 in the general surgery department of the university hospital (CHU) Gabriel Touré. We have included the patients whose age are superior to 15 years whose diagnosis of postoperative peritonitis was made based on clinical, biological, radiological and confirmed intraoperatively in all age patients. Non postoperative peritonitis were excluded. The primary endpoint was the highlight of the lesion responsible for postoperative peritonitis (fistula, necrosis, perforation iatrogenic intra abdominal abscess residual) after laparotomy in all patients. The secondary endpoints were:

- The presence of abdominal symptoms (not laxation, abdominal distension, parietal suppuration) and/or extra-abdominal (fever, septic shock, jaundice) in postoperative period. We made samples of pus for cytology examination to isolate the germ. Imaging (Ultrasound Scanner) and biology were carried out systematically in cases of abdominal distension, clinical signs of perforation or multiorgan failure.

- The prognosis in these patients was assessed using the score Mannheim prognostic index (MPI).

For data, we used:

- Registers operative report, the consultation registers and medical records of patients. Entry and data analysis were performed using the epi info software version 7. Testing validity of the results is the Chi-square test with a probability level of $p<0.001$ (and in cases where the theoretical size is $<5$, we used the test of validity of Fisher). The study was conducted with the consent of patients.

\section{Results}

\subsection{Epidemiology}

In 14 years, we achieved record 23573 lantern and 148 cases of postoperative peritonitis or $0.62 \%$. It was about 80 hommes (54.1\%) and 68 women (45.9\%). The average age was $37 \pm 1$ years 17.7 (13 - 80). The outcome of digestive fluid and abdominal pain were the main warning signs respectively $23.6 \%$ (35 cases) and 21.6\% (32 cas). The delay between the initial intervention and reoperation was less than 5 days. Patients were initially operated in emergency in $81.1 \%$ of cases.

\subsection{Clinic Found Most Were Clinical Signs}

Fever 27.7\% ( $=41)$, hypotension 37.2\% ( $=55)$, abdominal distension $21.6 \%(n=32)$, the cry of the umbilicus $66.9 \%(n=99)$, diffuse dullness $22.3 \%(n=33)$ and abdominal contracture $47.3 \%(n=70)$. Other signs are summarized in Table 1. Ultrasonography was performed in 44 patients (29.7\%) found an effusion. The review identified cytobacteriologic germs in $85.1 \%(n=126)$ and sterile in $12.9 \%$ of patients $(n=22)$.

\subsection{Intraoperative Findings}

All patients were operated. Intraoperatively, we noted the presence of pus in varying amounts in all patients $100 \%$. The most frequent etiologies were: $22.9 \%$ anastomotic leak $(n=34)$, the phrenic abscess in $17.6 \%(n=$ 26), iatrogenic perforation $13.5 \%(n=20)$ and digestive fistula $25 \%(n=37)$. Other causes were the stomiale necrosis $12.2 \%(n=18)$ and evisceration $8.8 \%(n=13)$. Gestures made: we conducted a sample of pus for bac- 
teriological examination and administered broad spectrum antibiotics pending the identification of germs. Digestive stoma was performed in $61 \%(n=89)$. Of these, $12.2 \%$ had a small bowel necrosis in that necrosis carrying a resection was performed previously. For patients with evisceration, we proceeded to the closure of the abdomen bolsters $8.8 \%(n=13)$. A suture in iatrogènes13 perforations, $5 \%(n=20)$. Washing with drainage were performed in patients with phrenic abscess in $17.6 \%(n=26)$, but also in other patients $82.4 \%(n=122)$. Surgery: they were single in $24.3 \%$ of cases $(n=36)$ and complicated in $22.3 \%$ of patients with type of wound infection $17.6 \%$ and $4.7 \%$ external digestive fistulas. A sample of the pus was made for cytology examination with susceptibility and local care have helped identify these infections. For digestive fistulas, they have dried in time is an 18 days. Mortality was $53.4 \%(n=79)$ due to septic shock.

\section{Discussion}

The diagnosis of postoperative peritonitis is difficult because of the latent nature of local symptoms which makes the often misleading and non-specific clinical signs. There are no specific laboratory test to reject or confirm the diagnosis. This atypical clinic is responsible for a delay of reoperation. [5]. Early reoperation before organ failure remains the major concern of the surgeon. After laparotomy, post operative peritonitis is the most common cause $50 \%$ - 83\% of surgical times [6]. We collected 148casesan incidence 10.5 cases per year and a frequency of 0.6 laparotomy (Table 1). This frequency is close to that reported in the literature [7] while others have found a rate of between $2 \%$ to $3.4 \%$ [8]-[11]. The average age in our study was 37.1 years close to that reported in Ivory Coast [12] but younger than in Europe [13] [14]. Sex is not a risk factor for postoperative peritonitis occurred while a male predominance has been reported by many authors [13] [15] [16]. The diagnostic delay is a derogatory mortality factor of $46.6 \%$, however our postoperative peritonitis were diagnosed during the first postoperative week (less than 5 days) with $31.8 \%$ of early diagnosis. Clinical semi logy of postoperative peritonitis is not specific and often recognized late. Digestive signs that we have recorded: $47.3 \%$ contracture, the abdominale 23 pain, $6 \%, 21.6 \%$ and distention after digestive fluid $21.6 \%$ are reported in the literature [14] [15] to varying frequencies but close to ours. We noted against by a frequency difference in signs extradigestifs with others [14] [17], it is $27.7 \%$ of the fever, hypotension, $37.2 \%, 12.2 \%$ tachycardia, vomiting and hiccups $10.1 \%$ 8.1\%. Biological signs, mostly found in our observation was anemia with a hemoglobin level below 10 $\mathrm{g} / \mathrm{dl}$ in $55.11 \%$ of patients against the leukocytosis for studies in Cote d'Ivoire and England [6] [12]. We believe this is due to initial conditions and diagnostic delay. It is based on imaging diagnosis of postoperative peritonitis is confirmed and the decision of reoperation in urgent need [8]. The injected scanner is the gold standard for objectively digestive walls and collections. But due to its unavailability at any time, its high cost, we asked the ultrasound that is more accessible to patients. Morphological signs were marked by the presence of effusion on ultrasound in 29.7\% (44/55). We believe that the operator dependence of ultrasound is the explanation. The antibiotic has been used based on isolated nuclei and their sensitivity (Table 2). Peritonitis by anastigmatic disunion is the most common etiology of postoperative peritonitis [8] [18]. In our study we recorded more than 37 digestive fistulas (25\%) (Table 3) as anastigmatic leak reported in the literature as the most common [8] [15]. We believe that these errors or technical errors are attributable to the surgeon and co-morbidities related field. The determinant of postoperative treatment of peritonitis is the reoperation [1]. Early or late recovery is a prognostic factor [1] [8] that can [19] reported a mortality of $61 \%$ among patients carrying an organ failure in cases of early reoperation ( $<24$ hours) against $88 \%$ in operating again patients beyond the 24 th hour. Surgical procedures performed in our series were digestive stoma $61 \%(n=89)$, the closure of the abdomen bolsters in $8.8 \%(n=13)$, a

Table 1. Postoperative peritonitis and different authors.

\begin{tabular}{ccccc}
\hline Authors & Period of Study & Size of Sample & Postoperative Peritonitis \% & $\mathrm{p}$ Value \\
\hline Roehrborn A. Allemagne, [2] & 2001 & 5812 & 2.0 & $\mathrm{p}<0.001$ \\
Drăghici L. Roumanie, [7] & 2012 & 18,676 & 0.9 & $\mathrm{p}=0.1$ \\
Hssaida R Maroc, [11] & 2000 & 16 & 2.1 & $\mathrm{p}<0.001$ \\
Coulibaly B Mali, [10] & 2013 & 724 & 3.4 & $\mathrm{p}<0.001$ \\
Our Study Mali & 2013 & 23,573 & 0.6 & \\
\hline
\end{tabular}


Table 2. Other clinical signs found in patients.

\begin{tabular}{ccc}
\hline Clinical signs & Number & $\%$ \\
\hline Anemia & 82 & 55.11 \\
Parietale suppuration & 25 & 16.5 \\
Tachycardia & 18 & 12.2 \\
Elevated serum creatinine concentrations & 17 & 11.5 \\
Vomiting & 15 & 10.1 \\
Leucocytosis & 14 & 9.5 \\
Hiccup & 12 & 8.1 \\
\hline
\end{tabular}

Table 3. Bacteria and sensitivity of antibiotic.

\begin{tabular}{ccc}
\hline Bacteria & Number & Sensitivity of Antibiotic \\
\hline E. coli & $70 / 126$ & Ceftriaxone \\
Enterocoques & $30 / 126$ & Amoxicilline + Gentamycine \\
B. fragilis & $16 / 126$ & Metronidazole et Clindamycine \\
S. aureus & $10 / 126$ & Amoxicilline + Acid Clavulanique
\end{tabular}

Table 4. Wilting postoperative peritonitis of different authors.

\begin{tabular}{|c|c|c|c|c|}
\hline Injury Authors & $\begin{array}{l}\text { Roehborn A. Allemagne, } \\
2001 \text { [2] } n=112\end{array}$ & $\begin{array}{l}\text { Augustin P France, } \\
2010[14] \mathrm{n}=41\end{array}$ & $\begin{array}{l}\text { Bader Allemagne } \\
2009[13] \mathrm{n}=114\end{array}$ & $\begin{array}{c}\text { Our Study Mali GT, } \\
2013 n=148\end{array}$ \\
\hline Digestive Fistula & - & $9(22.0 \%)$ & - & 37 (25\%) \\
\hline Disunion Anastomosis & $44(66 \%)$ & $14(34.0 \%)$ & $58(50.9 \%)$ & $34(22.9 \%)$ \\
\hline Intra-Abdominal Abscesses & $9(13 \%)$ & $10(24 \%)$ & $3(5.4 \%)$ & $26(17.6 \%)$ \\
\hline Perforation Iatrogenic & $7(10 \%)$ & $16(39.0 \%)$ & 26 (22.8\%) & $20(13.5 \%)$ \\
\hline Necrosis Intestinale & - & - & - & $18(12.2 \%)$ \\
\hline Evisceration & - & - & - & $13(8.8 \%)$ \\
\hline
\end{tabular}

suture perforations iatrogènes13.5\% $(n=20)$ washing and drainage in all patients. We recorded a morbidity of $22.3 \%$, with the predominant complication fistula (25\%). This result is lower than those of Degremont 50\% in France [20] and Gonollu Turkey 32.4\% [21]. The overall mortality rate of postoperative intra-abdominal infections is variable. The mortality rate in our study was $53.4 \%$, or more than half of patients (Table 4). This result is higher than Dellinger 29\% [3] and Chichom 29.8\% [22] but lower than Nel 71\% [4]. The causes of death in our series were acute renal failure, hepatic and septic shock.

\section{Conclusion}

Postoperative peritonitis is a serious complication of abdominal surgery, often difficult to diagnose. Support based on a multidisciplinary approach in which the surgeon, anesthetist and intensives radiologist plays a significant role. Only an early and effective therapeutic management can reduce morbidity and mortality in our country.

\section{References}

[1] Montravers, P., Gauzit, R., Muller, C., Marmuse, J.P., Fichelle, A. and Desmonts, J.M. (1996) Emergence of Antibiotic-Resistant Bacteria in Cases of Peritonitis after Intraabdominal Surgery Affects the Efficacy of Empirical Antimi- 
crobial Therapy. Clinical Infectious Diseases, 23, 486-494. http://dx.doi.org/10.1093/clinids/23.3.486

[2] Roehrborn, A., Thomas, L., Potreck, O., Ebener, C., Ohmann, C., Goretzki, P.E., et al. (2002) The Microbiology of Postoperative Peritonitis. Clinical Infectious Diseases, 33, 1513-1519. http://dx.doi.org/10.1086/323333

[3] Dellinger, E., Wertz, M., Meakins, J., Solomkin, J., Allo, M. and Howward, H. (1985) Surgical Infection Stratification System for Intra-Abdominal Infection. Archives of Surgery, 120, 21-29. http://dx.doi.org/10.1001/archsurg.1985.01390250015003

[4] Nel, C.J., Pretorius, D.J. and De Vaal, J.B. (1986) Re-Operation for Suspected Intra-Abdominal Sepsis in the Critically Ill Patients. South African Journal of Surgery, 24, 60-62.

[5] Kunin, N., Bansard, J.Y., Leto Quart, J.P., et al. (1991) Facteurs Pronostiques de Péritonites du sujet âgé à propos de 216 Observations. Journal de Chirurgie, 128, 481-486.

[6] Hutchins, R.R., Gunning, M.P., Lucas, D.N., et al. (2004) Relaparotomy for Suspected Intraperitoneal Sepsis after Abdominal Surgery. World Journal of Surgery, 28, 137-141. http://dx.doi.org/10.1007/s00268-003-7067-8

[7] Draghici, L., Ungureanu, A., et al. (2012) Laparoscopic Surgery Complications: Post Operative Peritonitis. Journal of Medicine and Life, 5, 288-296.

[8] Mariette, C. (2006) Principes de prise en charge chirurgicale des péritonites post opératoires. Journal de Chirurgie, 143, 84-87. http://dx.doi.org/10.1016/S0021-7697(06)73619-5

[9] Wittgrove, A.C. and Clark, C.V. (2000) Laparoscopic Gastric Bypass, Roux en-y, 500 Patients: Techniques and Results with 3-6 Months Follow up. Obesity Surgery, 10, 233-239. http://dx.doi.org/10.1381/096089200321643511

[10] Coulibaly, B., Coulibaly, M., et al. (2013) Péritonites Post Opératoires dans le service de chirurgie B du CHU Point G. Mali Médical, 3, 10-13.

[11] Hssaida, R., Daali, M., Seddiki, R., Zoubir, M. et al. (2000) Les péritonites postopératoires chez le sujet âgé. Médecine du Maghreb.

[12] Mignonsin, D., Kane, M., Coffi, S., et al. (1990) Péritonites post opératoires: Diagnostic, traitement et pronostic. Médecine d'Afrique Noire, 37, 397-401.

[13] Mulari, K. and Leppäniemi, A. (2004) Severe Secondary Peritonitis Following Gastrointestinal Tract Perforation. Scandinavian Journal of Surgery, 93, 204-208.

[14] Robert, R., Hutchins, M.S., Paul Gunning, M., et al. (2004) Relaparotomy for Suspected Intraperitoneal Sepsis after Abdominal Surgery. World Journal of Surgery, 28, 137-141. http://dx.doi.org/10.1007/s00268-003-7067-8

[15] Bader, F.G., Schroder, M., Kujath, P., et al. (2009) Diffuse Postoperative Peritonitis—Value of Diagnostic Parameters and Impact of Early Indication for Relaparatomy. European Journal of Medical Research, 14, 491-496. http://dx.doi.org/10.1186/2047-783X-14-11-491

[16] Augustin, P., Kermarrec, N., Muller-Serieys, C., et al. (2010) Risk Factors for Multidrug Resistant Bacteria and Optimization of Empirical Antibiotic Therapy in Postoperative Peritonitis. Critical Care, 14, R20.

[17] Montravers, Ph., El Housseini, L. and Rekkit, R. (2004) Les péritonites postopératoires: Diagnostic et indication des réinterventions. Réanimation, 13, 431-435.

[18] Gainant, A. (2000) Prévention des déhiscences anastomotiques en chirurgie colorectale. Journal de Chirurgie, 137, 4550.

[19] Bohnen, J., Boulanger, M., Meakins, J. and Mc Lean, P. (1983) Prognosis in Generalised Peritonitis: Relation to Cause and Risk Factors. Archives of Surgery, 118, 285-290. http://dx.doi.org/10.1001/archsurg.1983.01390030017003

[20] Degremont, R., Brehant, O. and Fuks, D. (2011) Prise en charge des péritonites sus-mésocoliques postopératoires par drainage de Lévy (drain hélisonde). Journal de Chirurgie Viscérale, 148, 327-335. http://dx.doi.org/10.1016/j.jchirv.2011.03.014

[21] Gonullu, D., Koksoy, F.N., Demiray, O., et al. (2009) Laparostomy in Patients with Severe Secondary Peritonitis. Turkish Journal of Trauma \& Emergency Surgery, 15, 52-57.

[22] Chichom, A., Tchounzou, R., Essomba, A., et al. (2009) Ré interventions de chirurgie abdominale en milieu défavorisé: Indications et suites opératoires (238 cas). Journal de Chirurgie, 146, 387-391. http://dx.doi.org/10.1016/j.jchir.2009.08.018 
Scientific Research Publishing (SCIRP) is one of the largest Open Access journal publishers. It is currently publishing more than 200 open access, online, peer-reviewed journals covering a wide range of academic disciplines. SCIRP serves the worldwide academic communities and contributes to the progress and application of science with its publication.

Other selected journals from SCIRP are listed as below. Submit your manuscript to us via either submit@scirp.org or Online Submission Portal.
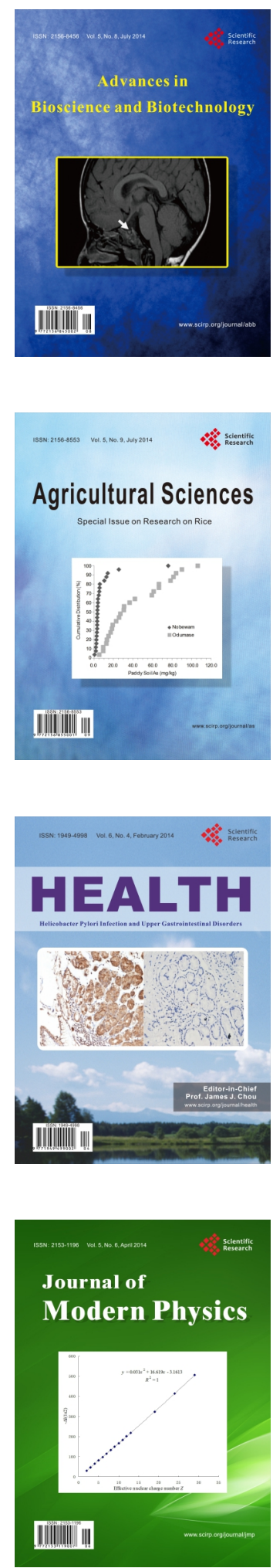
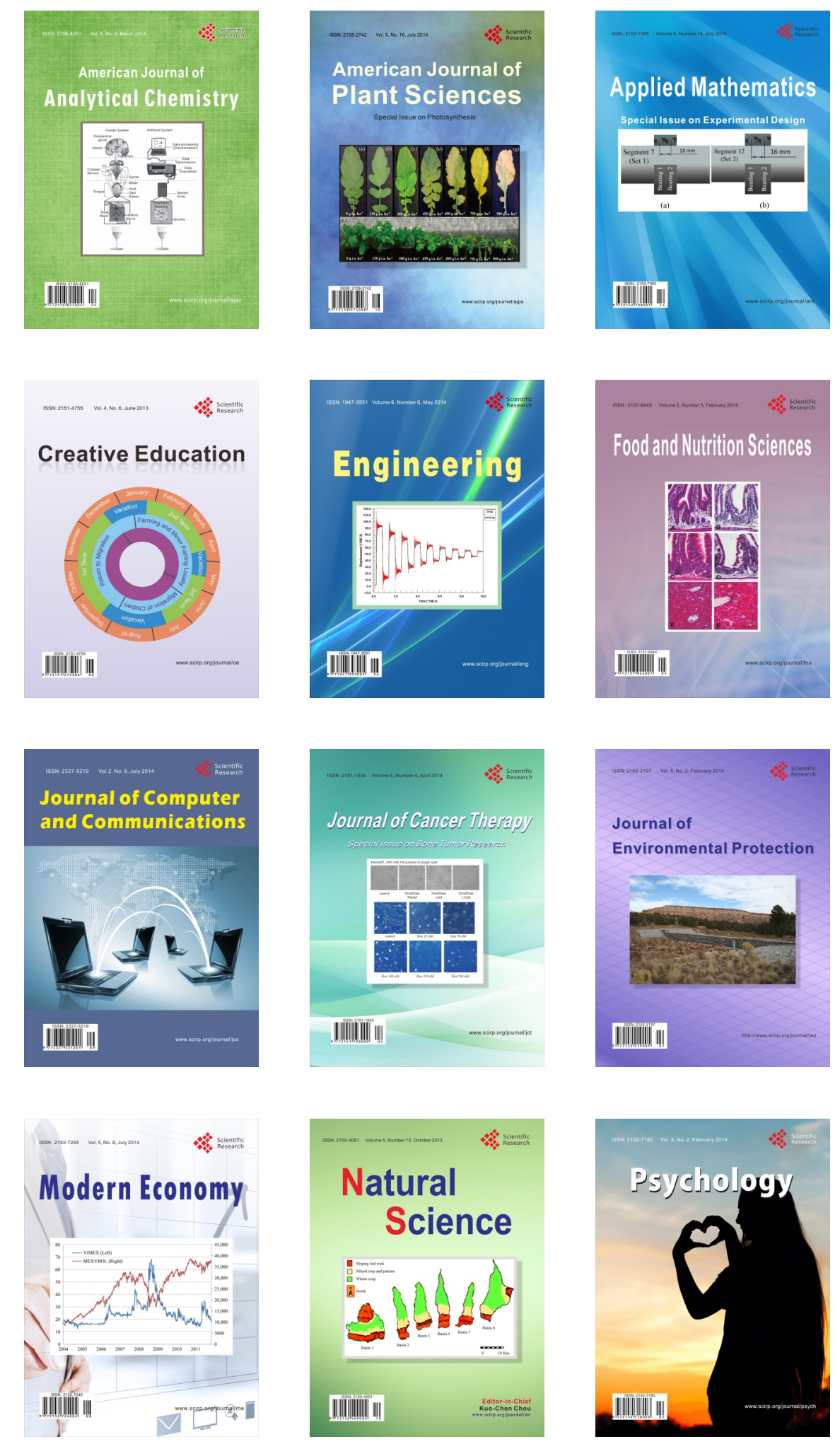